\title{
FAKTOR YANG BERHUBUNGAN DENGAN PEMBERIAN KOLOSTRUM PADA BAYI BARU LAHIR DI PRAKTEK BIDAN SYAMSIAH KABUPATEN TAPANULI SELATAN TAHUN 2018
}

\section{The Related Factors To The Giving Of Colostrum On Neonatal At Syamsiah Maternity Practical South Tapanuli District In 2018}

\author{
Suyanti Suwardi ${ }^{1 *}$, Debby Pratiwi ${ }^{2}$, Julina Br Sembiring ${ }^{2}$ \\ ${ }^{1}$ Dosen D4 Kebidanan, Fakultas Farmasi Dan Kesehatan, Institut Kesehatan Helvetia, Medan, Indonesia \\ ${ }^{2}$ Dosen D3 Kebidanan, Akademi Kebidanan Helvetia, Medan, Indonesia \\ "Penulis Korespondensi email:suyantisuwardi@ helvetia.ac.id
}

\begin{abstract}
Abstrak
Pendahuluan; World Health organization (WHO) tahun 2016 menunjukkan ada 170 juta anak mengalamigizi kurang di seluruh dunia. Sebanyak 3 juta anak di antaranya meninggal tiaptahun akibat kurang gizi. Angka kematianbayi yang cukup tinggi di dunia,sebenarnya dapat dihindari dengan pemberian Air Susu Ibu (ASI). Tujuan; Penelitian ini bertujuan untuk mengetahui faktor berhubungan dengan Pemberian Kolostrum Pada Bayi Baru Lahir di Praktek Bidan Syamsiah Kabupaten Tapanuli Selatan Tahun 2018. Metode; penelitian dalam survei analitik dengan pendekatan cross sectional. Populasi penelitian ini adalah ibu post partum yang melahirkandi Praktek Bidan Syamsiah Kabupaten Tapanuli Selatan tahun 2018 berjumlah 37 orang (Accidental sampling). Hasil; Dari hasil penelitian 37 responden, berdasarkan hasil uji statistik dengan menggunakan ChiSquare di dapatkanHubungan Pengetahuan dengan Pemberian Kolostrum Pada Bayi Baru Lahir diperoleh nilai $\mathrm{p}=0,000<0,05$, faktor dukungan keluarga dengan pemberian kolostrum pada bayi baru lahirdiperolehnilaip $=0,007>0,05$, faktor pekerjaan dengan pemberian kolostrum pada bayi baru lahir di Praktek Bidan Syamsiah Kabupaten Tapanuli Selatan Tahun 2018diperolehnilaip=0,001<0,05.maka Ho ditolak dan Ha diterima Kesimpulan; Disarankan kepada Praktek Bidan Syamsiahuntuk memberi penyuluhan dan pelayanan khususnya mengenai pemberian Kolostrum pada bayi baru lahir sehingga meningkatkan pengetahuan dan pengalaman bagi ibu post partum.

Kata Kunci : Perawatan Payudara, Kelancaran ASI
\end{abstract}

\begin{abstract}
Background; World Health Organization (WHO) in 2016 shows that there are 170 million children experiencing malnutrition worldwide. As many as 3 million children die each year due to malnutrition. The high infant mortality rate in the world can actually be avoided by doing breastfeeding. Objectives; This study aims to determine the related factors to the giving of colostrum on neonatal at Syamsiah Maternity Practical of South Tapanuli District in 2018. Method; The research design is an analytical survey with a cross sectional approach. The population of this study was postpartum mothers who gave birth at Syamsiah Maternity Practical of South Tapanuli District in 2018 totaling 37 people (Accidental sampling). Result;Based on the results of the study 37 respondents, based on the results of statistical tests using Chi-Square get the knowledge relationship with giving of colostrum to neonatal obtained $p$ value $=0.000<0.05$, family support factor by giving of colostrum to neonatal obtained $p=0.007>0.05$, the factor of work by giving of colostrum to neonatal at Syamsiah Maternity Practical of South Tapanuli District in 2018 obtained p value = $0.001<0.05$. Then Ho was rejected and Ha was accepted. Conclusion; It is suggested to the Syamsiah Maternity Practical to provide counseling and services especially regarding the giving of Colostrum in neonatal to increase knowledge and experience for postpartum mothers.
\end{abstract}

Keywords: Breast Care, Smoothness of Breastmilk

\section{PENDAHULUAN}

Ibu setelah melahirkan pada hari pertama dan kedua tidak jarang yang mengatakan ASInya belum keluar.Sebenarnya meski ASI yang keluar pada hari tersebut sedikit menurut ukuran kita, tetapi volume kolostrum yang ada dalam payudara 
mendekati kapasitas lambung bayi yang berusia $1-2$ hari.Kolostrum diproduksi pada beberapa hari pertama setelah bayi dilahirkan. Kolostrum mengandungbanyak protein dan antibodi, walaupun sangat kental dan jumlahnya sangat sedikit.Pada masa awal menyusui, kolostrum yang keluar mungkin hanya sesendok teh.Meskipun sedikit, kolostrum mampu melapisi usus bayi dan melindunginya dari bakteri sertasanggup mencukupi kebutuhan nutrisi bayi pada hari pertama kelahirannya. Selanjutnya, secara berangsur-angsurproduksi kolostrum berkurang saat air susu keluar pada hari ketiga sampai kelima.

Tidak ada satupun susu formula yang dapat menggantikan perlindungan kekebalan tubuhseorang bayi, seperti yang diperoleh dari kolostrum, yaitu ASI yang dihasilkan setelah kelahiran. Air Susu Ibu adalah makanan yang paling penting terutama pada bulan-bulan pertama kehidupan. Komposisi zat-zat gizi di dalam ASI secara optimal mampu menjamin pertumbuhan bayi.Komposisi gizi ASI yang paling baik adalah pada tiga hari pertama setelah lahir yang dinamakan kolostrum.

Kolostrum adalah cairan pertama yang disekresi oleh kelenjar payudara. Kandungan tertinggi dalam kolostrum adalah antibodi yang siap melindungi bayi ketika kondisi bayi masih sangat lemah. Kandungan protein dalam kolostrum lebih tinggi dibandingkan dengan kandungan protein dalam susu matur. Pemberian kolostrum secara awal pada bayi dan pemberian ASI secara terus menerus merupakan perlindungan yang terbaik pada bayi karena bayi dapat terhindar dari penyakit dan memiliki zat anti kekebalan 10-17 kali daripada susu matang/matur(1).

Terdapat beberapa pengertian dan persepsi yang salah mengenai kolostrum, yang diperkirakan ASI yang kotor, sehingga tidak patut diberikan pada bayi. Ternyata kolostrum sebagai pembuka jalan agar bayi dapat menerima ASI penuh.Kolostrum banyak mengandung antibodi dan anti-infeksi serta dapat menumbuh kembangkan flora dalam usus bayi, untuk siap menerima ASI(1).
WHO (World Health Organization) merekomendasikan pada ibu di seluruh dunia untuk menyusui secara eksklusif pada bayinya dalam 6 bulan pertama setelah lahir untuk mencapai pertumbuhan yang optimal, perkembangan dan kesehatan.Pemerintah mendukung kebijakan WHO dan Unicef yang merekomendasikan inisiasi menyusui dini sebagai tindakan penyelamatan kehidupan karena inisiasi menyusui dini dapat menyelamatkan $22 \%$ dari bayi yang meninggal sebelum usia satu bulan. Menyusui satu jam pertama kehidupan yang diawali dengan kontak kulit antara ibu dan bayi dinyatakan sebagai indikator global(2).

Pada saat pertama kali menyusui, seorang ibu akan menghasilkan kolostrum yang kemudian menjadi ASI matur. Manfaat kolostrum sangat penting bagi bayi baru lahir. The world Alliance for breasfeding action ( $W A B A)$, juga memperkirakan satu juta bayi dapat diselamatkan jika diberikan ASI pada satu jam pertama kelahiran. Kemudian dilanjutkan ASI eklusif sampai 6 bulan bulan pertama. Dalam standar nasional World Health Organisation ( WHO $), \quad$ juga merekomendasikan bahwa semua bayi perlu mendapatkan kolostrum yang bertujuan dapat melawan penyakit infeksi yang diperkirakan dapat menyelamatkan satu juta nyawa bayi(3).

Di negara berkembang, saat melahirkan, minggupertama melahirkan merupakanperiode kritis bagi ibu dan bayinya, sekitar dua pertiga kematian terjadi pada masa neonatal, dua per tiga kematian neonatal terjadi pada minggu pertama dan hari pertama. Hal ini selaras dengan tujuan pembangunan kesehatan atau Sustainable Development Goals (SDGs) nomor 3 (Tiga), yaitu pada tahun 2030, mengakhiri kematian bayi dan balita yang dapat dicegah, dengan seluruh negara berusaha menurunkan Angka Kematian Neonatal setidaknya hingga 12 per 1.000 Kelahiran Hidup dan Angka Kematian Balita 25 per 1.000 Kelahiran Hidup(4).

Rangka menurunkan angka kesakitan dan kematian anak, United Nation Childrens Fund (UNICEF) dan World Health 
Organizatin (WHO) merekomendasikan sebaiknya anak hanya disusui air susu ibu (ASI) selama paling sedikit 6 bulan. Cakupan pemberian ASI eksklusif di Indonesia tahun 2014 sebesar 52,3\%, hal ini menunjukkan bahwa cakupan pemberian ASI eksklusif belum mencapai target sebesar $80 \%$. Menurut provinsi, hanya terdapat satu provinsi yang berhasil mencapai target yaitu Provinsi Nusa Tenggara Barat sebesar $84,7 \%$. Provinsi Jawa Barat (21,8\%), Papua Barat $(27,3 \%)$, dan Sumatera Utara $(37,6 \%)$ ini merupakan tiga provinsi dengan capaian terendah pemberian ASI eksklusif(5).

Berdasarkan Undang-Undang Nomor 36 Tahun 2009 tentang Kesehatan, Peraturan Pemerintah Republik Indonesia Nomor: 33 Tahun 2012 tentang Pemberian Air Susu Ibu (ASI) Eksklusif, Peraturan Bersama Menteri Negara Pemberdayaan Perempuan, Menteri Tenaga Kerja dan Transmigrasi dan Menteri Kesehatan, Nomor: 48/MEN.PP/XII/2008, Nomor: PER.27/MEN/XII/2008 dan Nomor: 177/MENKES/PB/XII/2008 tentang Peningkatan Pemberian Air Susu Ibu Selama Waktu Kerja di Tempat Kerja serta mempertimbangkan hasil Riset Kesehatan Dasar (Riskesdas) tahun 2013 disebutkan bahwa presentase pemberian ASI saja (ASI eksklusif) pada bayi sampai usia 6 bulansebesar 30,2\% sedangkan target nasional sebesar $75 \%(6)$.

Berdasarkan Riskesdas (2013), diperoleh bahwa persentase perilaku ibu di Indonesia yang membuang kolostrum baik sebagian maupun seluruhnya adalah sebesar $25,3 \%$. Untuk wilayah Sumatera Utara didapati angka yang lebih tinggi yaitu sebesar $28,2 \%$. Perlakuan ibu bayi terhadap kolostrum, yang dikategorikan menjadi tiga, yaitu : 1) diberikan semua kepada bayi, 2) dibuang sebagian kemudian diberikan kepada bayi, dan 3) dibuang semua diketahui, bahwa hasil Riskesdas tahun 2010 yaitu 74,7 diberikan semua, 16,9 dibuang dan 8,4 dibuang semua. Hasil Riskesdas tahun 2013 yaitu, 85,3 diberikan semua, 8,9 dibuang dan 5,9 dibuang semua(7).
Berdasarkan profil kesehatan Sumatera Utara tahun 2016, Kabupaten/Kota dengan pencapaian $\geq 40 \%$ untuk Kabupaten yaitu Labuhan Batu Utara (97.90\%), Samosir (94.8\%), Humbang Hasundutan (84.0\%), Simalungun (60.6\%), Dairi (55.7\%), Pakpak Bharat (50.5\%), Deli Serdang (47.1\%), Asahan (43.6\%), Labuhan Batu (40.9\%) dan untuk Kota yaitu Gunung Sitoli (84.5\%), Sibolga (46.7\%). Daerah dengan pencapaian < $10 \%$ yaitu Kota Medan (6.7\%), TebingTinggi (7.4\%). Cakupan ASI eksklusif di Kabupaten Tapanuli Selatan sebesar 401 orang $(16,25 \%)$ dari 2.468 orang jumlah sasaran bayi.(8)

Pemahaman masyarakat bahwa susu yang keluar pertama kali adalah "susu basi" atau kotor sehingga harus dibuang terlebih dahulu. Pemahaman ini umumnya turun temurun dari ibu atau neneknya dengan bersumber pada asumsi, latar belakang budaya dan keyakinan serta ketidaktahuan individu. Roesli, mengungkapkan bahwa hal-hal yang menyebabkan ibu nifas tidak memberikan kolostrum dengan segera diantaranya, kolostrum tidak keluar atau jumlah kolostrum tidak memadai, kolostrum dianggap kotor dan tidak seharusnya diberikan pada bayi, kolostrum tidak baik dan berbahaya bagi bayi serta bayi takut kedinginan.

Menyusui sejak dini mempunyai dampak yang positif baik bagi ibu maupun bayinya.Menyusui mempunyai peran penting untuk menunjang pertumbuhan, kesehatan, dan kelangsungan hidup bayi karena ASI kaya akan zat gizi dan antibodi. Sedangkan bagi ibu, menyusui dapat mengurangi morbiditas dan mortalitas karena proses menyusui akan merangsang kontraksi uterus sehingga mengurangi perdarahan pasca melahirkan (postpartum)(9)

Pelaksanaan sangat erat hubungannya dengan pemberian kolostrum. Kenyataannya dimasyarakat masih banyak ibu yang belum mengetahui tentang begitu besarnya manfaat kolostrum bagi bayi dan menganggap kolostrum sebagai susu basi yang bisa membuat bayinya muntah atau sakit sehingga mereka cenderung membuang kolostrum itu 
dan tidak menyusukan kepada bayinya. Hal ini menunjukkan bahwa masih kurangnya pengetahuan ibu tentang kolostrum.(10)

$$
\text { Penelitian Desti Astuti yang }
$$
mengatakan bahwa yang menghambat ibu nifas memberikan kolostrum dengan segera, diantaranya takut bayi kedinginan, setelah melahirkan ibu terlalu lelah untuk menyusui bayinya, kolostrum tidak keluar atau jumlah kolostrum tidak memadai, serta kolostrum tidak baik dan berbahaya bagi bayi. Hal di atas tidak akan terjadi jika seorang ibu nifas mempunyai pengetahuan yang bagus serta mendapat dukungan dari keluarga(11)

Berdasarkan hasil survei awal yang dilakukan, data yang diperoleh peneliti dari Klinik Syamsiahpada bulan Juni 2018, diperoleh jumlah bayi sebanyak 32 orang. Hasil wawancara pada 10 orang ibu postpartum, sebanyak 7 orang ibu postpartum yang tidak memberikan kolostrum dan yang memberikan kolostrum sebanyak 3 orang. Dimana 7 orang ibu postpartum tidak mengetahui tentang kolostrum sehingga kurangnya informasi yang didapat tentang manfaat kolostrum. Kurangnya pengetahuan tentang kolostrum menyebabkan ibu-ibu percaya kepada mitos-mitos bahwa ASI yang keluar pertama kali itu kotor, hal ini menyebabkan adanya kebiasaan dikalangan ibu untuk membuang kolostrum (ASI yang pertama kali keluar) serta masih kurangnya dukungan keluarga/suami tentang pentingnya memberika kolostrum.Kurangnya informasi yang didapatkan dari petugas kesehatan dan waktu luang ibu dalam memberikan ASI.Sementara 3 orang mengatakan sudah mengetahui tentang manfaat kolostrum bayi.(12)

Hal ini diduga disebabkan karena sampai saat ini masih kurang penyuluhan maupun kegiatan promosi kesehatan lainnya terkait IMD sehingga dapat mempengaruhi pengetahuan dan sikap ibu terhadap pemberian kolostrum. Selain itu, tidak semua petugas kesehatan yang membantu persalinan menerapkan proses IMD pada ibu bersalin serta dukungan dari keluarga terutama suami kurang didapatkan ibu sehingga pemberian kolostrum tidak terlaksana(13).

Berdasarkan uraian tersebut, peneliti tertarik untuk melakukan penelitian yang berjudul "Faktor Yang Berhubungan Dengan Pemberian Kolostrum Pada Bayi Baru Lahir Di Praktek Bidan Syamsiah Kabupaten Tapanuli Selatan Tahun 2018”.

Tujuan Untuk mengetahui distribusi frekuensi pengetahuan ibu Di Praktek Bidan Syamsiah Kabupaten Tapanuli Selatan Tahun 2018.

\section{METODE}

Jenis penelitian ini adalah penelitian survei analitik adalah penelitian yang mencoba menggali bagaimana dan mengapa fenomena kesehatan itu terjadi. Penelitian ini menggunakan desain cross sectionalyaitu jenis penelitian yang berusaha mempelajari dinamika hubungan hubungan atau korelasi antara faktor-faktor resiko dengan dampak atau efeknyayaituuntuk mengetahui Faktor Yang Berhubungan Dengan Pemberian Kolostrum Pada Bayi Baru Lahir Di Praktek Bidan Syamsiah Kabupaten Tapanuli Selatan Tahun 2018.

Penelitian ini dilakukan di Praktek Bidan Syamsiah Kabupaten Tapanuli Selatan, alasan karena masih banyak ibu yang tidak memberikan kolostrum dikarenakan pengetahuannya kurang serta masih kurangnya dukungan dari keluarga terhadap pemberian kolostrum.Penelitian ini dilakukan pada bulan Juni-September2018

\section{HASIL}

\section{Analisa Univariat}

Analisa Univariat digunakan untuk mendeskripsikan data yang dilakukan pada tiap variabel dari hasil penelitian.Data yang terkumpul disajikan dalam bentuk tabel distribusi frekuensi.

Berdasarkan table 1 dapat diketahui bahwa dari 37 responden,ibu yang berpengetahuan baik sebanyak 8 orang $(21,6 \%)$, berpengetahuan cukup sebanyak 19 orang $(51,4 \%)$, dan berpengetahuan kurang 
sebanyak 10 orang $(27,0 \%)$.dapat diketahui bahwa dari 37 responden,petugas kesehatan tidak mendukung sebanyak 25 orang $(67,6 \%)$, mendukung sebanyak 12 orang $(32,4 \%)$.diketahui bahwa dari 37 responden, ibu mendapat dukungan keluarga sebanyak 16 orang $(43,2 \%)$, dan ibu tidak mendapat dukungan keluaraga sebanyak 21 orang (56,8\%).dapat diketahui bahwa dari 37 responden, ibu bekerja sebanyak 12 oarng $(32,4 \%)$, dan ibu tidak bekerja sebanyak 25 orang $(67,6 \%)$.diketahui bahwa dari 37 responden, di berikan kolostrum pada bayi baru lahir sebanyak 23 orang $(62,2 \%)$, dan tidak diberikan sebanyak 14 orang $(37,8 \%)$.

Distribusi Frekuensi Pengetahuan Ibu Pada Pemberian Kolostrum Pada Bayi Baru Lahir Di Praktek Bidan Syamsiah Kabupaten Tapanuli Selatan Tahun 2018

\begin{tabular}{ccc}
\hline Distribusi & \multicolumn{2}{c}{ Jumlah } \\
\cline { 2 - 3 } & $\mathrm{f}$ & $\%$ \\
\hline Pengetahuan & 8 & 21,6 \\
Baik & 19 & 51,4 \\
Kukup & 10 & 27,0 \\
\hline Dukungan Petugas Kesehatan & \\
\hline Tidak mendukung & 67,6 \\
Mendukung & 25 & 32,4 \\
\hline Dukungan keluarga & 12 & \\
\hline Mendukung & & 53,2 \\
Tidak Mendukung & 16 & \\
\hline Pekerjaan & 21 & 32,4 \\
\hline Bekerja & & 67,6 \\
\hline Tidak Bekerja & 12 & 62,2 \\
\hline Pemberian Kolostrum & 25 & 37,8 \\
\hline Diberikan & & \\
\hline Tidak diberikan & 23 & \\
\hline
\end{tabular}

Analisa Bivariat

Berdasarkan table 1 dapat diketahui bahwa dari 37 responden, ibu yang berpengetahuan baik sebanyak 8 orang $(21,6 \%)$, dimana berpengetahuan baik dengan tidak memberikan kolostrum pada bayi baru lahir berjumlah 6 orang $(6,2 \%)$, berpengetahuan baik dengan memberikan kolostrum pada bayi baru lahirberjumlah 2 orang $(5,4 \%)$. Ibu yang berpengetahuan cukupsebanyak 19 orang $(51,4 \%)$, dimana berpengetahuan cukup dengan tidak memberikan kolostrum pada bayi baru lahir berjumlah 17 orang $(45,9 \%)$ dan memberikan kolostrum berjumlah 2 orang $(5,4 \%)$, dan berpengetahuan kurang memberikan kolostrum pada bayi baru lahir berjumlah 10 orang (27\%).7 dapat diketahui bahwa dari 37 responden, ibu yang mendapat dukungan keluarga sebanyak 16 orang $(43,2 \%)$, dimana ada dukungan keluarga dengan pemberian kolostrum pada bayi baru lahir berjumlah 10 orng $(27,0 \%)$ dan tidak memberikan kolostrum berjumlah 6 orang $(16,2 \%)$. Ibu yang tidak mendapatkan dukungan keluarga sebanyak 21 orang $(56,8 \%)$, dimana ibu tidak ada dukungan keluarga dengan tidak memberikan kolostrum berjumlah 17 orang $(45,9 \%)$ dan memberikan kolostrum berjumlah 4 orang $(10,8 \%)$. dapat diketahui bahwa dari 37 responden, ibu yang mendapat dukungan dari petugas kesehatan sebanyak 12 orang $(32,4 \%)$, dimana memberikan kolostrum berjumlah 10 orang $(27,0 \%)$ dan tidak memberikan kolostrum 
berjumlah 2 orang $(5,4 \%)$. Ibu yang tidak mendapat dukungan dari petugas kesehatan sebanyak 25 orang $(67,6 \%)$, dimana tidak memberikan kolostrum berjumlah 21 orang $(56,8 \%)$ danmemberikan kolostrum berjumlah 4 orang $(10,8 \%)$. diketahui bahwa dari 37 responden, ibu yang tidak bekerja sebanyak 25 orang $(67,6 \%)$, dimana tidak memberikan kolostrum berjumlah 20 orang $(54,1 \%)$ dan memberikan kolostrum berjumlah 5 orang $(13,5 \%)$. ibu yang bekerja sebanyak 12 orang $(32,4 \%)$, dimana tidak memberikan kolostrum berjumlah 3 orang $(8,1 \%)$ dan memberikan kolostrum berjumlah 9 orang $(24,3 \%)$.

Tabulasi Silang Antara faktor pengetahuan dengan Pemberian Kolostrum Pada Bayi Baru Lahir Di Praktek Bidan Syamsiah Kabupaten Tapanuli Selatan Tahun 2018

\begin{tabular}{|c|c|c|c|c|c|c|c|}
\hline \multirow{3}{*}{ Distribusi } & \multicolumn{4}{|c|}{ Pemberian Kolostrum } & \multirow{2}{*}{\multicolumn{2}{|c|}{ Total }} & \multirow{3}{*}{$\begin{array}{c}\text { Asymp. } \\
\text { Sig }\end{array}$} \\
\hline & \multicolumn{2}{|c|}{ Tidak Diberikan } & \multicolumn{2}{|c|}{ Diberikan } & & & \\
\hline & $\mathrm{f}$ & $\%$ & $f$ & $\%$ & $\mathrm{f}$ & $\%$ & \\
\hline \multicolumn{8}{|l|}{ Pengetahuan } \\
\hline Baik & 6 & 6,2 & 2 & 5,4 & 8 & 21,6 & \multirow{3}{*}{0.000} \\
\hline Cukup & 17 & 45,9 & 2 & 5,4 & 19 & 51,4 & \\
\hline Kurang & 0 & 0 & 10 & 27,0 & 10 & 27,0 & \\
\hline \multicolumn{8}{|l|}{ Dukungan Keluarga } \\
\hline Tidak mendukung & 17 & 45,9 & 4 & 56,8 & 21 & 56,8 & \multirow[b]{2}{*}{0.007} \\
\hline Mendukung & 6 & 16,2 & 10 & 27,0 & 16 & 43,2 & \\
\hline \multicolumn{8}{|l|}{ Dukungan kesehatan } \\
\hline Tidak Mendukung & 21 & 56,8 & 4 & 10,8 & 25 & 67,6 & \multirow{2}{*}{0.000} \\
\hline Mendukung & 2 & 5,4 & 10 & 27,0 & 12 & 32,4 & \\
\hline \multicolumn{8}{|l|}{ pekerjaan } \\
\hline Tidak Bekerja & 20 & 54,1 & 5 & 13,5 & 25 & 67,6 & \multirow{2}{*}{0.001} \\
\hline Bekerja & 3 & 8,1 & 9 & 24,3 & 12 & 32,4 & \\
\hline
\end{tabular}

\section{PEMBAHASAN}

Faktor Pengetahuan Dengan Pemberian Kolostrum Pada Bayi Baru Lahir

Faktor Pengetahuan dengan Pemberian Kolostrum Pada Bayi Baru Lahir Di Praktek Bidan Syamsiah Kabupaten Tapanuli Selatan Tahun 2018, berdasarkan hasil analisis uji statistic chi-square diperoleh nilai $\mathrm{p}=$ $0,000<0,05$ maka dapat disimpulkan bahwa ada Hubungan Pengetahuan dengan dengan Pemberian Kolostrum Pada Bayi Baru Lahir.

Pengetahuan merupakan domain yang sangat penting untuk terbentuknya perilaku terbuka (overt behavior).Perilaku yang didasari pengetahuan umumnya bersifat lebih bertahan.Ada hubungan antara tingkat pengetahuan ibu dengan kelengkapan imunisasi balita sesuai dengan teori yang dinyatakan bahwa seseorang melakukan tindakan dengan didasarkan oleh suatu pengetahuan.Hal ini disebabkan karena pengetahuan merupakan domain yang sangat penting untuk terbentuknya tindakan seseorang.Penelitian yang dilakukan oleh Mayasari \& Fakhidah (2017) menyatakan bahwa faktor pengetahuan memegang peranan penting dalam pemberian kelengkapan imunisasi dasar, karena pengetahuan mendorong kemauan dan kemampuan masyarakat, sehingga akan diperoleh suatu manfaat terhadap keberhasilan imunisasi secara lengkap. Maulana menyatakan bahwa dimana pengetahuan merupakan pedoman dalam membentuk tindakan seseorang.Perilaku baru khususnya pada orang dewasa diawali oleh pengetahuan, selanjutnya muncul sikap terhadap objek yang diketahuinya.Setelah objek diketahui dan disadari sepenuhnya kemudian timbul respon berupa tindakan (14). 
Penelitian ini sejalan dengan penelitian yang dilakukan Eni Rumiyati dengan judul Hubungan Tingkat Pengetahuan Ibu Menyusui Dengan Pemberian Asi Pertama (Kolostrum) Di Rumah Bersalin An-Nissa Surakarta, didapat hasil Tingkat pengetahuan ibu baik tentang pemberian kolostrum sebanyak 20 orang $(66,67 \%)$, tingkat pengetahuan ibu cukup baik tentang pemberian kolostrum sebanyak 5 orang $(16,67 \%)$, tingkat pengetahuan ibu kurang tentang pemberian kolostrum sebanyak 1 orang(3,33\%), dan tingkat pengetahuan ibu tidak baik dan tidak memberikan kolostrum sebanyak 3 orang $(10 \%)$. Nilai $\mathrm{p}=0,000<0,05$, artinya terdapat hubungan antara tingkat pengetahuan ibu menyusui dengan pemberian ASI pertama (kolostrum) di Rumah Bersalin An-Nissa Surakarta (11)

$$
\text { Rumiyati }
$$

mengatakanPengetahuan ibu dapat dipengaruhi olehtingkat pendidikian ibu, semakin tinggipendidikan ibu semakin tinggi pula tingkatpengetahuannya terhadap manfaat dankeunggulan ASI kolostrum. Tingkatpengetahuan ibu menyusui tentangmanfaat pemberian kolostrum membuat ibu akan termotivasi untuk memberikankolostrum pada bayinya.Notoatmodjo dalam Tarigan danErniyati, menyatakan bahwapengetahuan merupakan pedoman dalammembentuk tindakan dan perilakuseseorang. Adanya pengetahuan akanmenimbulkan kesadaran seseorang yang Akhirnya memicunya untuk berperilakusesuai dengan pengetahuan yangdimilikinya tersebut.

$$
\text { Hasil penelitian ini sejalan }
$$
denganpenelitian yang dilakukan oleh Pitri, R, $S$, yang dalam penelitiannya berjudul"FaktorFaktor Yang Berhubungan denganPemberian Kolostrum Pada Bayi Baru LahirDi Klinik Sari Medan" yang mengatakanbahwa ada hubungan yang signifikanantara pengetahuan dengan pemberiankolostrum pada bayi ( $\mathrm{P}$ volue $=0,0001)$.Disarankan pada petugas tenagakesehatan hendaknya meningkatkanpemberian informasi atau penyuluhankepada ibu-ibu tentang pemberiankolostrum(15).

Kendala pemberian kolostrum adalah kekurangtahuan atau karena kepercayaan yang salah, banyak ibu yang baru melahirkan tidak memberikan kolostrum kepada bayinya. Diberbagai daerah, air susu pertama (kolostrum) sengaja diperah dengan tangan dan dibuang. Kandungan kolostrum inilah yang tidak diketahui ibu sehingga banyak ibu dimasa setelah persalinan tidak memberikan kolostrum kepada bayi baru lahir karena pengetahuan tentang kandungan kolostrum itu tidak ada.

Berdasarkan hal tersebut di atas,maka peneliti berasumsi bahwa adapengaruh yang signifikan antara pengetahuan dengan pemberian kolostrum pada bayi. Kolostrum adalah sesuatu yang sangat khusus, kolostrum kaya akanprotein, immunoglobulin, vitamin, bahan anti-infeksi, misalnya laktoferin dan lisozim, sel-sel hidup, serta mineral. Kolostrum memberi perlindungan bagi bayi yang baru lahir sampai system imunnya sendiri mulai berfungsi, dan memastikan bahwa systempencernaan bayi mulai berfungsi denganbenar, serta mengandung semua gizi yangdibutuhkannya(16).

Pengetahuan ibu tentang kolostrum yang baik tetapi tidak memberikan kolostrum dapat disebabkan karena ASI yang tidak lancar atau belum keluar. Adapun untuk yang pengetahuannya kurang tetapi memberikan kolostrum dapat disebabkan karena inisiasi menyusu dini yang berhasil dilakukan pada saat persalinan.

\section{Faktor Dukungan Petugas} Kesehatan Dengan Pemberian Kolostrum Pada Bayi Baru Lahir

Faktor Dukungan Petugas Kesehatan dengan Pemberian Kolostrum Pada Bayi Baru Lahir Di Praktek Bidan Syamsiah Kabupaten Tapanuli Selatan Tahun 2018, berdasarkan hasil analisis uji statistic chi-square diperoleh nilai $\mathrm{p}=0,000<0,05$, maka dapat disimpulkan bahwa ada hubungan antara faktor Faktor Dukungan Petugas Kesehatandengan 
Pemberian Kolostrum Pada Bayi Baru Lahir (17).

Hasil penelitian ini mendukung penelitian sebelumnya oleh Putu (2015) yang menyimpulkan ada hubungan antara dukungan tenaga kesehatan tentang kolostrum dengan pemberian kolostrum ( $p$ value $=0,001)$. Penelitian lain oleh Khoniasari (2015)menyimpulkan ada hubungan antara peran tenaga kesehatan dengan pelaksanaan inisiasi menyusu dini. Tenaga kesehatan yang dapat menjalankan perannya dengan baik dapat meningkatkan keberhasilan pemberian kolostrum pada bayi baru lahir, khususnya bidan yang menolong persalinan(18).

Petugas kesehatan setelah selesai menolong persalinan dapat memberikan penjelasan tentang pentingnya ibu untuk segera memberikan kolostrum. Pemberian ASI secara ekslusif ada hubungannya dengan peran petugas kesehatan, sikap dan perhatian oleh para ahli kesehatan yang berkaitan dengan menyusui sangat diperlukan terutama dalam membantu terlaksananya inisiasi menyusui dini dan menghadapi promosi pabrik pembuat susu formula dan pemberian makanan pendamping ASI seperti pisang, madu, bubur nasi. Posisi strategis dari peranan instansi kesehatan dan para petugas kesehatan di Indonesia terutama di puskesmas sangat bermanfaat bagi pelaksanaan kegiatan operasional pemasyarakatan ASI. Salah satu upaya untuk meningkatkan keberhasilan pemberian kolostrum adalah melalui pelaksanaan Inisiasi Menyusu Dini (IMD) oleh bayi baru lahir pada ibunya. IMD adalah bayi mulai menyusu sendiri segera setelah lahir, dimana bayi dibiarkan mencari puting susu ibunya sendiri (tidak disodorkan ke puting susu). Tenaga kesehatan khususnya bidan memiliki peran penting dalam menolong persalinan. Pemberian kolostrum dapat dilakukan melalui pelaksanaan inisiasi menyusu dini. Oleh karena itu, tenaga kesehatan dalam menolong persalinan harus lebih aktif dalam pelaksanaan inisiasi menyusu dini untuk memastikan bayi baru lahir segera mendapatkan kolostrum yang sangat penting bagi pertumbuhan dan perkembangannya(19).

Faktor Dukungan KeluargaDengan Pemberian Kolostrum Pada Bayi Baru Lahir

Faktor dukungan keluarga dengan pemberian kolostrum pada bayi baru lahir Di Praktek Bidan Syamsiah Kabupaten Tapanuli Selatan Tahun 2018, berdasarkan hasil analisis uji statistic chi-square diperoleh nilai $\mathrm{p}=$ 0,007>0,05, maka dapat disimpulkan bahwa Faktor dukungan keluaraga dengan pemberian kolostrum pada bayi baru lahir Di Praktek Bidan Syamsiah Kabupaten Tapanuli Selatan Tahun 2018

Dukungan keluarga adalah sikap, tindakan penerimaan keluarga terhadap anggota keluarganya, berupa dukungan informasional, dukungan penilaian, dukungan instrumental dan dukungan emosional.Keseluruhan elemen tersebut terwujud dalam bentuk hubungan interpersonal yang meliputi sikap, tindakan dan penerimaan terhadap anggota keluarga, sehingga anggota keluarga merasa ada yang memperhatikan (20)..

Keluarga dapat menciptakan suasana yang menyenangkan.Perhatian keluarga terutama ayah kepada ibu yang sedang menyusui untuk memberikan dukungan dan membesarkan hatinya bahwa menyusui merupakan anugerah dan tugas yang mulia Penelitian ini sesuai dengan Freadman (2010), dukungan keluarga adalah sikap, tindakan dan penerimaan keluarga terhadap anggotanya.Anggota keluarga dipandang sebagai bagian yang tidak terpisahkan dalam lingkungan keluarga.Anggota keluarga memandang bahwa orang yang bersifat mendukung selalu siap memberikan pertolongan dan bantuan jika diperlukan Keberhasilan pemberian ASI ekslusifditentukan oleh peran keluarga, terutamasuami. Selama proses ini berlangsung,peran suami sama pentingnya denganperan ibu. Peran suami yang paling utamaadalah menciptakan suasana dan situasikondusif yang memungkinkan 
pemberianASI berjalan lancar. Selain memenuhikebutuhan ibu (terutama kebutuhan akanzat gizi yang baik selama menyusui), suamidapat berperan sebagai penghubungdalam menyusui dengan membawa bayikepada ibu saat dia lapar. Peran suami,keluarga, dan semua pihak, sangatmembantu keberhasilan pemberian ASIekslusif.Menurut Roesli dalam Elinofia, RitaD, Roma U, yang mengatakanPeran seorang ayah telah terbukti menjadisalah satu pengaruh yang paling kuatterhadap keputusan ibu untuk menyusui.Namun masih banyak para ayah yangberpendapat salah.

Para ayah berpendapatbahwa menyusui adalah urusan ibu danbayinya. Mereka menganggap cukupmenjadi pengamat yang pasif saja.Sebenarnya ayah mempunyai peran yangsangat menentukan dalam keberhasilanmenyusui karena ayah akan turut menentukan kelancaran reflek pengeluaran ASI (let down reflek) yang sangatdipengaruhi oleh keadaan emosi atauperasaan ibu. Ayah dapat berperan aktifdalam keberhasilan pemberian ASI denganjalan memberikan dukungan secaraemosinal. Pengertian tentang peran penyayang penting inimerupakan langkah pertama bagi seorang ayah untuk dapat mendorong ibu agar berhasil menyusuisecara eksklusif(10).

Hasil penelitian ini sejalan denganpenelitian yang dilakukan olehSeptianingrum, T, K, Suparni, Prasojo S, yang dalam penelitiannya berjudul “ Hubungan DukunganKeluarga TerhadapIbu Dengan Pemberian ASI KolostrumDiruang Cempaka Rsud Kraton KabupatenPekalongan" yang mengatakan bahwa adahubungan yang signifikan antara dukungankeluarga dengan pemberian kolostrumpada bayi $(P$ value $=0,024)$. Tingginyaangka kesakitan bayi terkait dengankemampuan seorang ibu dalam pemberianASI kolostrum yang tidak memadai kepadabayinya.

Berdasarkan hal tersebut di atas,maka peneliti berasumsi bahwa ada hubungan yang signifikan antara dukungankeluarga dengan pemberian kolostrumpada bayi. Dukungan keluarga dalam hal ini adalah keterlibatan keluarga dalam merawat bayi dan memberikan informasi mengenai ASI kepada ibu. Hasil tersebut dapat dilihat bahwa responden yang mendapat informasi tentang ASI dari keluarganya akan terdorong untuk memberikan ASI dibandingkan dengan yang tidak pernah mendapatkan informasi atau dukungan dari keluarganya, sehingga dukungan keluarga berpengaruh terhadap pemberian ASI

\section{Faktor Pekerjaan IbuDengan} Pemberian Kolostrum Pada Bayi Baru Lahir

Faktor pekerjaandengan pemberian kolostrum pada bayi baru lahir Di Praktek Bidan Syamsiah Kabupaten Tapanuli Selatan Tahun 2018, berdasarkan hasil analisis uji statistic chi-square diperoleh nilai $\mathrm{p}=$ $0,001<0,05$, maka dapat disimpulkan bahwa ada hubunganAntara Faktor pekerjaandengan pemberian kolostrum pada bayi baru lahir.

$$
\text { Pekerjaan dapat menjadi }
$$

penggambaran kedudukan sosial dan kemampuan ekonomi yang dimiliki oleh seseorang. Hasil penelitian menunjukkan bahwa status pekerjaan ibu dengan distribusi tertinggi adalah pegawai swasta. Kondisi ibu yang bekerja, dan sifatnya terikat dengan pekerjaannya pada instansi swasta tempat ia bekerja menyebabkan ibu kurang memiliki waktu luang untuk merawat danmengasuh bayinya sehinggadapatmempeng aruhipola pemberian kolostrum kepada bayinya.

Terdapatnya responden yang bekerja namun tidak memberikan kolostrum disebabkan karena kesibukan ibu bekerja sehingga mengakibatkan kurangnya waktu dan pemahaman serta kurangnya pengetahuan sehingga responden kurang memahami tentang manfaat akan pentingnya kolostrum bagi tumbuh kembang bayi dan selain itu karena faktor lain seperti tidak adanya dukungan suami.

Hasil penelitian ini sejalan dengan penelitian yang dilakukan oleh Nellya Mulyani (2004), bahwa pekerjaan ibu tidak 
memberikan pengaruh langsung pada pemberian kolostrum pada bayi baru lahir.Pada Penelitian ini juga terdapat responden tidak bekerja namun memberikan kolostrum disebabkan karena responden memiliki waktu yang lebih banyak untuk merawat dan memperhatikan bayinya terutama mengantarnya secara rutin ke posyandu sehingga mendapat informasi tentang pentingnya kolostrum pada bayi baru lahir (5).

Begitupula ibu dengan status bekerja namun tetap memberikan kolostrum kurang dari 1 minggu karena ibu tersebut memiliki kesadaran yang tinggi akan pentingnya kesehatan bayinya dan banyaknya informasi yang diperolehnya sehingga tetap berusaha memberikan kolostrumnya. Sedangkan ibu dengan status bekerja dan tidak memberikan kolostrum pada bayinya yang berusia kurang dari 1 minggu, disebabkan karena ibu tersebut tidak memiliki waktu yang cukup untuk memberikan kolostrum kepada bayinya. Selain itu, aspek aktivitas ibu dalam rumah tangga turut mempengaruhi, dimana ibu yang memiliki aktivitas dalam rumah yang banyak seperti karena banyak anak menyebabkan waktu untuk mengurus anak terbagi yang pada akhirnya pemberian kolostrum pada bayi tidak terlaksana dengan baik.

\section{KESIMPULAN}

Ada hubungan yang signifikan antara pendidikan dengan pemberian kolostrum pada bayi baru lahir Di Praktek Bidan Syamsiah Kabupaten Tapanuli Selatan Tahun 2018, berdasarkan hasil analisis uji statistic chisquare diperoleh nilai

\section{SARAN}

Diharapakn bagi pendidikan untuk memberikan masukan atau informasi kepada penentu kebijakan dan pelaksanaan program bagi Puskesmas Kepayang Barat untuk mendalam menyusun program perencanaan berkaitan dengan upaya masalah yang ditimbulkan oleh perkembangan anak.
Peneliti ucapkan terima kasih kepada Bidan syamsiah yang telah memberikan kesempatan kepada peneliti untuk melakukan penelitian ini, dan terima kasih kepada seluruh pegawai Bidan syamsiah yang telah memberikan semangat dan motivasinya kepada peneliti

\section{DAFTAR PUSTAKA}

1. Ambarwati ER. Asuhan Kebidanan Nifas. Yogyakarta: Nuha Medika; 2015.

2. Cahyono AD. Hubungan Antara Pengetahuan Ibu Post Partum Tentang Manfaat Kolostrum Bagi Bayi Baru Lahir Dengan Perilaku Ibu Menyusui Dini. 2013.

3. Kemenkes. Profil Kesehatan Indonesia Tahun 2015. Jakarta2016.

4. Papona N. Hubungan Pengetahuan Dan Sikap Ibu Nifas Tentang Pemberian Kolostrum Pada Bayi Baru Lahir Di Puskesmas Ulu Kecamatan Siau Timur Kabupaten Kepulauan Sitaro 2013.

5. RI KK. Kesehatan Dalam Kerangka Sustainable Development Goals (SDGs) 2015.

6. Kemenkes. Profil Kesehatan Indonesia 2014. Jakarta2015.

7. Dinkes S. Profil Kesehatan Provinsi Sumatera Utara 2016.

8. Riskesdas. Riset Kesehatan Dasar Jakarta: Kementrian Kesehatan RI; 2013.

9. Khasanah N. ASI atau Susu Formula Ya. Yogyakarta: Flashbooks; 2013.

10. Astuti D. Tingkat Pengetahuan Ibu Nifas tentang Kolostrum dengan Motivasi Pemberian Kolostrum di Rumah Sakit Panembahan Senopati Bantul, Yogyakarta. 2015.

11. Nasihah M. Hubungan Pengetahuan Ibu Post Partum Tentang Manfaat

Kolostrum Dengan Pemberian Kolostrum Pada Bayi Baru Lahir Di Bps. Aida Hartatik Amd, Keb Ds.Dlanggu Kec. Deket Lamongan 20152015.

12. Rumiyati E. Hubungan Tingkat Pengetahuan Ibu Menyusui Dengan Pemberian Asi Pertama (Kolostrum) 
Di Rumah Bersalin An-Nissa Surakarta 2011.

13. Anggraini Y. Asuhan Kebidanan Masa Nifas. Yogyakarta: Pustaka Rihama; 2014.

14. Saleha s. Asuhan Kebidanan Pada Masa Nifas. Jakarta: Salemba Medika; 2009.

15. Prasetyono. Buku Pintar ASI Eksklusif. Jakarta: Diva Press; 2012.

16. Ronald. Pedoman \& Perawatan Balita Agar Tumbuh Sehat dan Cerdas. Bandung Nuansa Aulia; 2011.

17. Widyasih H. Perawatan Masa Nifas. Yogyakarta: Fitramaya; 2015.

18. Maryunani A. Ilmu Kesehatan Anak Dalam Kebidanan. Jakarta: Trans Info Media; 2015.

19. Wawan. Teori \& Pengukuran Pengetahuan, Sikap, dan Perilaku Manusia. Yogyakarta: Nuha Medika; 2015.

20. Hasanah. Konsep Dukungan Sosial Suami 2014 [cited 201720 Juni]. Availablefrom:http://etheses.uinmalang.ac.id/613/6/09410060\%20Bab \%202.pdf. 